\title{
Properties and Applications of Perovskite Proton Conductors
}

\author{
Eduardo Caetano Camilo de Souza*, Reginaldo Muccillo \\ Center of Science and Technology of Materials, \\ Energy and Nuclear Research Institute, \\ Travessa R 400, Cidade Universitária, CEP 05508-900, São Paulo, SP, Brazil
}

Received: March 24, 2010; Revised: September 27, 2010

\begin{abstract}
A brief overview is given of the main types and principles of solid-state proton conductors with perovskite structure. Their properties are summarized in terms of the defect chemistry, proton transport and chemical stability. A good understanding of these subjects allows the manufacturing of compounds with the desired electrical properties, for application in renewable and sustainable energy devices. A few trends and highlights of the scientific advances are given for some classes of protonic conductors. Recent results and future prospect about these compounds are also evaluated. The high proton conductivity of barium cerate and zirconate based electrolytes lately reported in the literature has taken these compounds to a highlight position among the most studied conductor ceramic materials.
\end{abstract}

Keywords: perovskites, proton conductivity, sustainable energy

\section{Introduction}

The mineral perovskite was discovered in the Ural Mountains, Russia, by Gustav Rose, in 1839, and received this name in tribute to the Russian mineralogist Lev Aleksevich von Perovski. Although the name perovskite was originally used to describe the mineral $\mathrm{CaTiO}_{3}$, currently it is commonly employed to name a specific group of oxides with general formula $\mathrm{ABO}_{3}$ and similar crystal structure. Compared to other oxide families such as pyrochlore, perovskite related compounds can be synthesized with a wide variety of combinations of chemical elements, because cations of large (site A) and small (site B) ionic radius fit well in the crystalline structure and in addition that structure is highly tolerant to vacancy formation. In these oxides with formula $\mathrm{ABO}_{3}$, the A-site can be filled either by cations $\mathrm{M}^{+}(\mathrm{Na}, \mathrm{K}), \mathrm{M}^{2+}$ $(\mathrm{Ca}, \mathrm{Sr}, \mathrm{Ba})$ or $\mathrm{M}^{3+}(\mathrm{Fe}, \mathrm{La}, \mathrm{Gd})$, and the $\mathrm{B}$-site can be occupied either by $\mathrm{M}^{5+}(\mathrm{Nb}, \mathrm{W}), \mathrm{M}^{4+}(\mathrm{Ce}, \mathrm{Zr}, \mathrm{Ti})$ or $\mathrm{M}^{3+}(\mathrm{Mn}, \mathrm{Fe}, \mathrm{Co}, \mathrm{Ga})$. As a result of the combination of different ions, the materials may present insulating, semiconducting, ionic conducting and superconducting behavior being useful for technological applications in sensor devices, refractories, electronic components, solid oxide fuel cells (SOFC), catalytic membrane reactors for hydrogen production, and so on ${ }^{1}$.

Table 1 lists the properties and applications of some commonly studied perovskites.

Solid electrolytes with perovskite structure, such as barium cerate $\left(\mathrm{BaCeO}_{3}\right)$ and barium zirconate $\left(\mathrm{BaZrO}_{3}\right)$ are applied in a variety of electrochemical devices. In all of them the electrolyte performs three essential functions: 1) separation of two chambers, of the oxidant and the reducer sides, 2) electronic insulator to force the electrical current to pass through an external circuit, and 3) high conduction of ions to provide the balance for the electronic current in the external circuit. Applications of proton conducting ceramics can be classified according to two fundamental functions: 1) electromotive force based on a chemical potential gradient, and 2) electrochemical hydrogen transport driven by an external power source. Using a proton conductor as an electrolyte in a chemical potential gradient, the generated voltage can be utilized as an electrical power source (SOFC) or a signal that depends on the chemical potential of hydrogen in a specified chamber (sensor). Protonic conductors can also perform as a pathway for preferential hydrogen transport when an external driving force is present. This function can be utilized as a hydrogen extraction from mixed gases or hydrogen production from hydrocarbons or alcohols ${ }^{24,25}$.

A solid oxide fuel cell is a conversion energy device that produces electricity and heat from the chemical reaction between a fuel $\left(\mathrm{H}_{2}\right.$, natural gas, ethanol, biodiesel) and an oxidant agent $\left(\mathrm{O}_{2}\right)$. In this specific type of electrochemical converter, the main components responsible for reduction and oxidation reactions (electrodes) and ion transport (electrodes and electrolyte) are solid state conductor ceramics. Similar to a battery, it is formed by two electrodes (cathode and anode) separated by an electrolyte, but unlike a battery it does not need any recharge, requiring a continuous feed by a specific fuel for electrical generation. The fuel such as $\mathrm{H}_{2}$, ethanol or biodiesel feed the anode and is oxidized, releasing electrons to the external circuit in the cathode direction, producing a direct current (dc). The $\mathrm{H}^{+}$ species produced spread through the proton conductor membrane to the cathode, where in the presence of oxygen and electrons from the external circuit, they react with $\mathrm{O}_{2}$ molecules leading to the formation of water vapor, as illustrated in Figure 1.

A motivation to study solid electrolytes based on barium cerates or barium zirconates in solid oxide fuel cells is the possibility of decreasing the operation temperature $\left(500-700{ }^{\circ} \mathrm{C}\right)$, relatively to the high temperature solid oxide fuel cells based on oxygen ion conductors $\left(800-1000{ }^{\circ} \mathrm{C}\right)$. This allows minimizing the reaction on the interfaces, implying in higher Nernst (E) voltages. Moreover, protonic conductor membranes allow the formation of water vapor on the cathode side, avoiding the dilution of the fuel vapor, other important factor to optimize the cell potential (E).

A large amount of the hydrogen consumed around the world is produced from the catalytic reforming of the natural gas and is used for the production of ammonium, fertilizers, methanol, and also in the petroleum refining process. Over the last few years special attention has been focused on development of hydrogen production technologies, mainly because it is a renewable fuel of high energy density, essential to supply some devices for energy production such as solid oxide fuel cells. Alternative processes for hydrogen production have been developed based on renewable fuels, 
Table 1. Properties and applications of perovskites.

\begin{tabular}{|c|c|c|c|}
\hline Property & Application & Material & References \\
\hline $\begin{array}{c}\text { Proton } \\
\text { conductivity }\end{array}$ & $\begin{array}{c}\text { SOFC } \\
\text { electrolyte } \\
\text { Hydrogen } \\
\text { sensor } \\
\mathrm{H}_{2} \text { production/ } \\
\text { extraction }\end{array}$ & $\begin{array}{c}\mathrm{BaCeO}_{3}, \mathrm{SrCeO}_{3} \\
\mathrm{BaZrO}_{3}\end{array}$ & $2,3,4$ \\
\hline $\begin{array}{c}\text { Ionic } \\
\text { conductivity }\end{array}$ & $\begin{array}{c}\text { Solid } \\
\text { electrolyte }\end{array}$ & $(\mathrm{La}, \mathrm{Sr})(\mathrm{Ga}, \mathrm{Mg}) \mathrm{O}_{3-\delta}$ & 5 \\
\hline $\begin{array}{c}\text { Mixed } \\
\text { conductivity }\end{array}$ & $\begin{array}{c}\text { SOFC } \\
\text { electrode }\end{array}$ & $\begin{array}{l}\mathrm{La}(\mathrm{Sr}, \mathrm{Ca}) \mathrm{MnO}_{3-\delta}, \\
\mathrm{LaCoO}_{3} \\
(\mathrm{La}, \mathrm{Sr})(\mathrm{Co}, \mathrm{Fe}) \mathrm{O}_{3-\delta}\end{array}$ & $6,7,8$ \\
\hline $\begin{array}{l}\text { Ferroelectric/ } \\
\text { piezoelectric }\end{array}$ & $\begin{array}{l}\text { Piezoelectric } \\
\text { transducer } \\
\text { Thermistor, } \\
\text { actuator }\end{array}$ & $\begin{array}{c}\mathrm{BaTiO}_{3}, \mathrm{~Pb}(\mathrm{Zr}, \mathrm{Ti}) \mathrm{O}_{3} \\
\mathrm{~Pb}(\mathrm{Mg}, \mathrm{Nb}) \mathrm{O}_{3}\end{array}$ & 9,10 \\
\hline Catalytic & Catalyst & $\mathrm{LaFeO}_{3}, \mathrm{La}(\mathrm{Ce}, \mathrm{Co}) \mathrm{O}_{3}$ & 11,12 \\
\hline $\begin{array}{l}\text { Electrical/ } \\
\text { dielectric }\end{array}$ & $\begin{array}{c}\text { Multilayer } \\
\text { capacitor } \\
\text { Dielectric } \\
\text { ressonator } \\
\text { Thin film } \\
\text { resistor }\end{array}$ & $\mathrm{BaTiO}_{3}, \mathrm{BaZrO}_{3}$ & 13 \\
\hline Magnetic & $\begin{array}{c}\text { Magnetic } \\
\text { memory } \\
\text { Ferromagnetism }\end{array}$ & $\mathrm{GdFeO}_{3}, \mathrm{LaMnO}_{3}$ & $14-16$ \\
\hline Optical & $\begin{array}{c}\text { Electrooptical } \\
\text { modulator } \\
\text { Laser }\end{array}$ & $\begin{array}{l}(\mathrm{Pb}, \mathrm{La})(\mathrm{Zr}, \mathrm{Ti}) \mathrm{O}_{3} \\
\mathrm{YAlO}_{3}, \mathrm{KNbO}_{3}\end{array}$ & $17-20$ \\
\hline $\begin{array}{c}\text { Super- } \\
\text { conductivity }\end{array}$ & Superconductor & $\begin{array}{c}\mathrm{Ba}(\mathrm{Pb}, \mathrm{Bi}) \mathrm{O}_{3}, \\
\mathrm{BaKBiO}_{3}\end{array}$ & $21-23$ \\
\hline
\end{tabular}

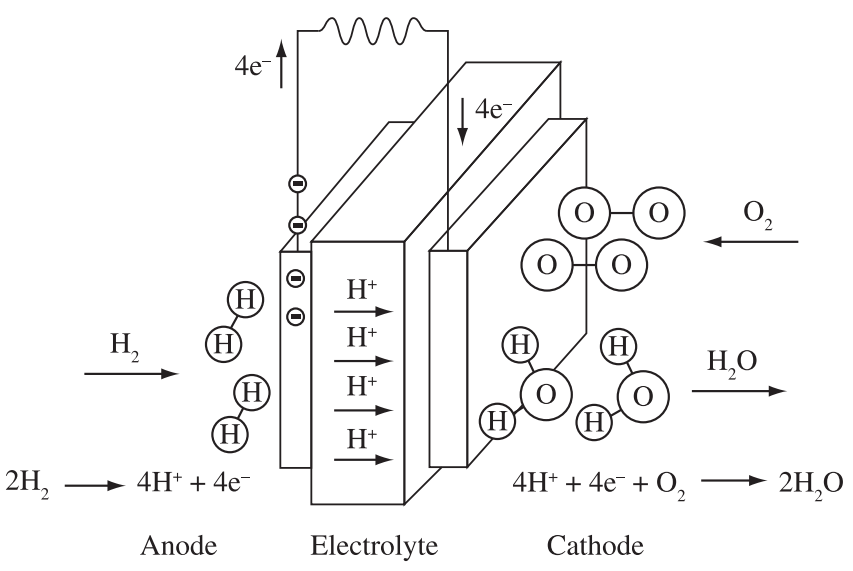

Figure 1. Representation of a solid oxide fuel cell based on proton conductor electrolyte. for instance: photo-electrolysis, photo-biologic processes, water electrolysis, thermolysis, etc. Initially, $\mathrm{H}_{2}$ can be also produced through steam reforming or partial oxidation of many other fuels as methanol, ethanol and biodiesel. In the presence of methane and water vapor, for example, the products of catalytic reforming are $\mathrm{H}_{2}$ and $\mathrm{CO}$. Then, hydrogen needs to be separated from the gas mixture to attain the suitable purity level to be commercialized ${ }^{26,27}$. In general, a high temperature in the range from 800 to $950{ }^{\circ} \mathrm{C}^{[28]}$ is necessary for an appropriate conversion of the natural gas in $\mathrm{H}_{2}$. The study of ceramic membranes of perovskite structure has received great attention, mainly due to the possibility of reducing that temperature regime $\left(500-700{ }^{\circ} \mathrm{C}\right)$ and also due to the low cost in relation to the commonly used palladium membranes ${ }^{29}$. Other great advantage in using the protonic conductor membranes such as barium zirconate is the possibility to perform, in the same electrochemical device, both processes of reforming and gas separation, simultaneously.

Ideally, the solid electrolyte must present ionic and electronic conductivities to avoid extra energy to protons migration to the cathode direction, minimizing energy losses. As yttrium doped barium zirconate is a predominantly ionic conductor, the mixture of metallic particles to the electrolyte has been suggested as an alternative to increase its electronic conduction. At the high operational temperature there is possibility of using low cost catalysts (eg. Ni) in both opposite surfaces of the membrane. Besides promoting the oxidation of the fuel and consequent production of hydrogen, the $\mathrm{H}_{2}$ molecules are also oxidized on the surface of the catalyst, generating protons and electrons, $2 \mathrm{H}^{+}+2 \mathrm{e}^{-}$, that spread through the mixed conductor up to the electrocatalyst corresponding to the cathode, where protons are reduced to produce $\mathrm{H}_{2}$, as can be observed in the Figure 2 .

\section{Perovskite Cubic Structure}

In the ideal perovskite structure with space group PM-3m, the sites correspondent to the A-cation are located at the vertices of the unit cell, B-site cations in the center, and oxygen ions at the faces, as illustrated in Figure 3. However, this structure is seldom attained at ambient conditions of temperature and pressure due to differences among the $\mathrm{A}, \mathrm{B}$ and $\mathrm{O}$ ionic radii. The Goldschmidt tolerance factor, $t$, based on the geometrical packing of charge spheres has been introduced to describe the distortion of the perovskite structure from the ideal configuration.

The Goldschmidt tolerance factor is determined taking into account the ionic radii of the species $\mathrm{A}, \mathrm{B}$ and $\mathrm{O}$, and can be written as (Equation 1):

$$
t=\frac{\left(r_{A}+r_{O}\right)}{\sqrt{2}\left(r_{B}+r_{O}\right)}
$$

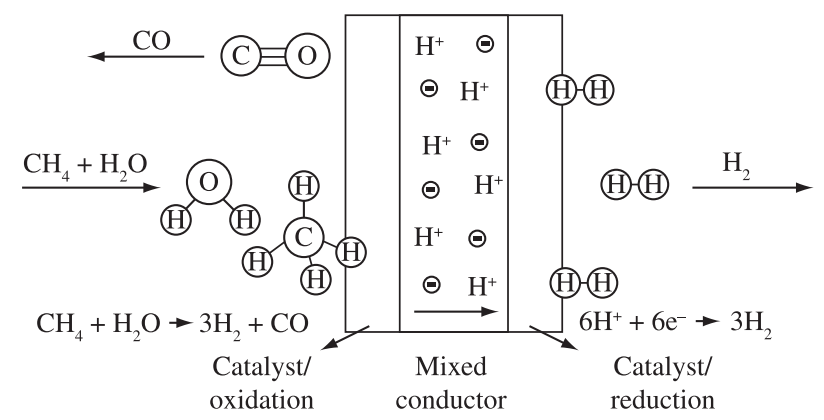

Figure 2. Illustration of hydrogen production from the mixture of methane and water. 


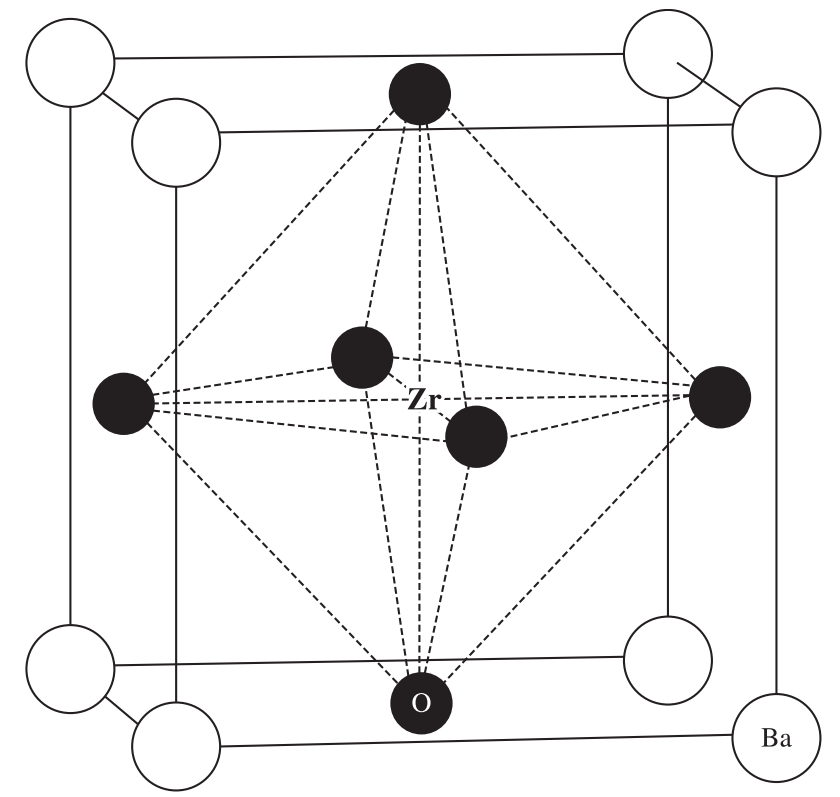

Figure 3. Schematic representation of the ideal perovskite structure, $\mathrm{ABO}_{3}$, with $\mathrm{A}=\mathrm{Ba}$ and $\mathrm{B}=\mathrm{Zr}$.

The ideally packed perovskite structure is considered simple cubic, as represented in Figure 3, presenting a tolerance factor $\mathrm{t}=1$. However, this structure may present some distortion from the ideal configuration, with $t$ varying in many cases between 0.75 and 1 , resulting in different systems such as orthorhombic, rhombohedral or tetragonal. K. S. Knight ${ }^{30}$ proposed four distortion mechanisms in perovskite structures: 1) distortions of the $\mathrm{BO}_{6}$ octahedra, 2) displacement of the B-site cation within the octahedron, 3) displacement of the A-site cation, and 4) tilting of the octahedrons relative to one another. The second and third mechanisms are typical of ferroeletric distortions in $\mathrm{BaTiO}_{3}$. The fourth is typically observed when the A-cation is too small for the dodecahedral site, such as $\mathrm{Sr}$ and $\mathrm{Ba}$ in $\mathrm{SrCeO}_{3}$ and $\mathrm{BaCeO}_{3}$.

The cubic structure of the barium cerate, $\mathrm{BaCeO}_{3}$, was initially reported by Hoffmann ${ }^{31}$ in 1934, and only in 1972 Jacobson et al. ${ }^{32}$ noted the presence of an orthorhombic distortion. Since the beginning of the 1980's this material has been extensively studied and Iwahara et al. ${ }^{3}$ started investigating the doped $\mathrm{BaCeO}_{3}$, and thereafter this protonic conductor was proved to be a potential electrolyte material in solid oxide fuel cells ${ }^{33}$. Consequently, several investigations about structure, transport properties and chemical stability of aliovalent cations doped $\mathrm{BaCeO}_{3}$ were reported, leading this oxide to be a promising proton conductor electrolyte for SOFC.

The structure and phase transitions of $\mathrm{BaCeO}_{3}$ have been investigated by several physical characterization techniques such as X-ray diffraction, neutron diffraction, Raman and infrared spectroscopies. As an example, the phase transitions of the barium cerate from room temperature to higher temperatures were investigated. ${ }^{30}$ It has been observed that the transition from the orthorhombic phase with space group Pmcn to other orthorhombic phase (Incn) occurs at $\sim 290{ }^{\circ} \mathrm{C}$ and then to rhombohedral $(F 32 / n)$ at $400{ }^{\circ} \mathrm{C}$. The crystallization in the cubic perovskite structure was detected only at higher temperatures $\left(900^{\circ} \mathrm{C}\right)$.

\section{Proton Conductivity}

Historically, the first conduction mechanism studied was the electron conductivity of metals and semiconductors. Subsequently, ionic conductors based on several chemical species such as lithium, sodium, potassium, silver, copper and oxygen ions were widely investigated and used to produce commercial devices. Compared to other ionic species, proton is the only one that due to its small size and lacking of electrons, connect to the anion with which is associated through the electrons of the valence shell. In the specific case of oxides, for example, the oxygen radius is $\sim 1,4 \AA$, while the length of the $\mathrm{O}-\mathrm{H}$ bond is $\sim 0,9 \AA^{34}$. The small size of the proton and the strong interaction with the oxide anion turn unlikely its jump from a crystallographic site to another. This fact has directed many research groups to the study and formulation of models associated with proton transport in oxides with perovskite structure, as will be described later.

The conductivity of each ionic species is directly proportional to the density of mobile ions, $n$, with a specific charge $\mathrm{q}$ and mobility $\mu$ (Equation 2).

$$
\sigma=n q \mu
$$

The density of the mobile species can be usually controlled via defect chemistry, whereas the mobility is a function of the intrinsic properties of the material and its temperature. The mobility $\mu$ can be described following the Nernst-Einstein equation (Equation 3):

$$
\mu=\frac{q D}{k_{B} T}
$$

where $\mathrm{k}_{\mathrm{B}}$ is the Boltzmann constant and the diffusivity D for each charge carrier can be expressed as a function that depends on the average carrier jump frequency $f$ and the distance of the jump, $\lambda$ (Equation 4):

$$
D=\frac{f \lambda^{2}}{6}
$$

The frequency $f$ can be described as derived from a thermally activated process, following the Equation 5:

$$
f=z w_{o} e^{-E_{a} / k_{B} T}
$$

where $\mathrm{z}$ is the number of directions in which the jump can occur, $\mathrm{w}_{\mathrm{o}}$ is a combination of activation entropy $\Delta \mathrm{S}$ and lattice vibration frequency $\mathrm{v}_{0}, \mathrm{w}_{0}=\mathrm{v}_{0} \mathrm{e}^{\Delta \mathrm{S} / \mathrm{k}_{\mathrm{B}}}$ and $\mathrm{E}_{\mathrm{a}}$ is the jump activation energy.

Combining Equations 2 to 5 results in the conductivity expression as a function of temperature (Equation 6):

$$
\sigma T=A e^{-E_{a} / k_{B} T}
$$

where

$$
A=\frac{z n w_{o .} q^{2} \lambda^{2}}{6 k_{B}}
$$

Through the expression of conductivity as a function of the reciprocal temperature it is possible to determine the activation energy $\mathrm{E}_{\mathrm{a}}$ for the ion transport (Equation 7).

$$
\ln (\sigma T)=\frac{E_{a}}{k_{B}} \frac{1}{T}+\ln A
$$

In general, in mixed conducting solid electrolytes electrons and holes require a low activation energy $(\sim 0.25 \mathrm{eV})$ for the conduction process, while for the $\mathrm{O}^{2-}$ ion conductivity the value of $\mathrm{E}_{\mathrm{a}}$ is much higher $(\sim 0.6-1.2 \mathrm{eV})^{35}$. In perovskites based on barium cerate and barium zirconate under saturated water vapor atmosphere and at an intermediate temperature range, 400 to $700{ }^{\circ} \mathrm{C}$, the electrical conductivity of these compounds is considered negligible, and the 
proton transport dominates the conduction mechanism. In this case, the activation energy for the proton conductivity has an intermediate value, varying in many cases from 0.4 to $0.6 \mathrm{eV}^{36,37}$. Conceptually speaking, these activation energy values mean, in a first interpretation, that the temperature dependence of the conductivity is lower in comparison to the oxygen ion conductors. Moreover, a minor energy to the proton transport indicates that these perovskites may present, at low temperatures, higher total conductivity than the ionic conductors based on cerium oxide. Hence the investigations of some properties, such as defect formation, proton transport and chemical stability have fundamental importance for the optimization of the proton conductivity. Taking this into account, there is a great possibility of employing those materials in electrochemical devices for generation of clean energy and hydrogen production, from renewable fuels such as ethanol and biodiesel.

\section{Defect Chemistry}

As already mentioned, several scientific papers have focused on the study of defect chemistry and transport properties of doped $\mathrm{BaCeO}_{3}$, after the first report of proton conductivity on that material ${ }^{3}$. The temperature and the atmosphere have significant influence on the transport properties in most of the ionic conductors. It has already been proved that, at specific temperature and $\mathrm{H}_{2} \mathrm{O} / \mathrm{H}_{2}$ partial pressure ranges, doped barium cerate presents a considerable proton conductivity ${ }^{24,38}$.

The introduction of defects into the perovskite structure and their distribution in the crystalline lattice are important factors that determine the proton conductivity. Ideally, the substitution of trivalent ions at $\mathrm{B}$-sites for $\mathrm{Ce}^{4+}$ occurs, according to the Kröger-Vink ${ }^{39}$ notation (Equation 8):

$$
2 \mathrm{Ce}_{\mathrm{Ce}}^{\mathrm{x}}+\mathrm{O}_{\mathrm{O}}^{\mathrm{x}}+\mathrm{M}_{2} \mathrm{O}_{3} \rightarrow 2 \mathrm{M}_{\mathrm{Ce}}^{\prime}+\mathrm{V}_{\mathrm{O}}^{\bullet \bullet}+2 \mathrm{CeO}_{2}
$$

However, factors such as atmosphere, non stoichiometry and size of the dopant influence defect formation. The substitution of the $\mathrm{Ba}^{2+}$ A-sites by a higher ionic radius dopant like $\mathrm{La}^{3+}$ or $\mathrm{Sm}^{3+}$ has been proposed after theoretical calculations ${ }^{40}$ (Equation 9).

$$
2 \mathrm{Ba}_{\mathrm{Ba}}^{\mathrm{x}}+\mathrm{M}_{2} \mathrm{O}_{3}+\mathrm{V}_{\mathrm{O}}^{\bullet \bullet} \rightarrow 2 \mathrm{M}_{\mathrm{Ba}}^{\bullet}+\mathrm{O}_{\mathrm{O}}^{\mathrm{x}}+2 \mathrm{BaO}
$$

This "reaction" consumes oxygen vacancy instead of creating new ones, lowering then the proton conductivity. Studying the phase equilibrium of the $\mathrm{Nd}_{2} \mathrm{O}_{3}-\mathrm{BaCeO}_{3}$ system, Makovec et al. ${ }^{41}$ proved experimentally that through the microanalysis of the formed solid solutions, they could be represented by a general formula $\mathrm{Ba}_{1-\mathrm{x}} \mathrm{Nd}_{\mathrm{x}} \mathrm{Ce}_{1-\mathrm{y}} \mathrm{Nd}_{\mathrm{y}} \mathrm{O}_{3-(\mathrm{y}-\mathrm{x}) / 2}$, in which the $\mathrm{Nd}^{3+}$ ion occupies both $\mathrm{Ba}^{2+}$ and $\mathrm{Ce}^{4+}$ sites. The ratio between the amounts of $\mathrm{Nd}^{3+}$ incorporated at $\mathrm{A}$ - and $\mathrm{B}$-sites is a function of the starting composition, varying from 1 in the part with larger $\mathrm{CeO}_{2}$ content to 0.1 in the part with larger $\mathrm{BaO}$ content of the $\mathrm{BaO}-\mathrm{CeO}_{2}-\mathrm{Nd}_{2} \mathrm{O}_{3}$ system. Thus, further studies have been proposed to investigate the substitution of $\mathrm{Ba}^{2+}$ sites for different ions and the consequent impact of these dopants in the proton conductivity of the barium cerate. Similarly, the effects of the aliovalent dopants on $\mathrm{Ce}^{4+}$ sites have not been explored completely and special attention is also important to consider. In the analysis of the influence of the $\mathrm{Ba}^{2+}$ content on the $\mathrm{Ba}_{x} \mathrm{Ce}_{0.9} \mathrm{Y}_{0.1} \mathrm{O}_{3-\delta}$ compounds, $0.8<\mathrm{x}<1.2$, Iwahara et $\mathrm{al}^{42}$ reported a maximum conductivity value of $\sim 0.015{\mathrm{~S} . \mathrm{cm}^{-1}}$ for that material at $600{ }^{\circ} \mathrm{C}$, for $\mathrm{x}=0.95$. Somewhat, the relatively high proton conductivities attained by that composition, comparable to the ionic conductivity of samarium doped ceria ${ }^{43}$, have influenced many research groups to choose yttrium as the dopant cation for the study of solid electrolytes based on $\mathrm{BaCeO}_{3}$.
Beyond the influence of the cation dopant, stoichiometry losses due to barium oxide volatilization given the high sintering temperatures $\left(>1500{ }^{\circ} \mathrm{C}\right)$ have also been considered a problem for the optimization of the proton conductivity. Hence, studies showing new directions towards the development of chemical synthesis methods and for powder processing techniques have been presented, aiming to decrease the sintering temperature of that material ${ }^{44-47}$. The densification is important to guarantee just the proton and not molecular transport in those compounds.

\section{Incorporation and Proton Transport Mechanisms}

When barium cerate is exposed to water vapor, oxygen vacancies are filled by hydroxyl groups. That means that protons are incorporated into the perovskite structure, as described by the equation of defect formation (Equation 10):

$$
\mathrm{H}_{2} \mathrm{O}_{(\text {gas })}+\mathrm{V}_{\mathrm{O}}^{\ddot{*}}+\mathrm{O}_{\mathrm{O}}^{\mathrm{x}} \longleftrightarrow 2 \mathrm{OH}_{\mathrm{O}}^{\bullet}
$$

The enthalpy of water incorporation or dissolution enthalpy $\left(\Delta \mathrm{H}_{\mathrm{H}_{2} \mathrm{O}}\right)$, which determines the extent of protonation at a given temperature, can be described as (Equation 11):

$$
\Delta \mathrm{H}_{\mathrm{H}_{2} \mathrm{O}}=2 \mathrm{E}_{\mathrm{OH}}-\mathrm{E}\left(\mathrm{V}_{\mathrm{O}}^{\bullet}\right)+\mathrm{E}_{\mathrm{PT}}
$$

$\mathrm{E}_{\mathrm{OH}}$ is the energy related with the substitution of $\mathrm{O}^{2-}$ by the hydroxyl group $\mathrm{OH}^{-}, \mathrm{E}\left(\mathrm{V}_{\mathrm{o}}^{*}\right)$ is the energy for creating an oxygen-ion vacancy and $\mathrm{E}_{\mathrm{PT}}$ the energy of the gas phase energy proton transfer reaction. Results of atomistic simulations yielded a negative water dissolution enthalpy for $\mathrm{CaZrO}_{3}, \mathrm{SrZrO}_{3}$ and $\mathrm{BaCeO}_{3}$, indicating that the proton conductivity is predominant at low temperatures in these perovskites, in agreement with experimental results ${ }^{40,48,49}$. It is known that the enthalpy of water incorporation, $\Delta \mathrm{H}_{\mathrm{H}_{2} \mathrm{O}}$, changes with the type of the dopant and in lower magnitude with its content. Theoretical calculations have indicated a change of $\mathrm{E}_{\mathrm{OH}}$ with different amounts of dopant and also that the association between proton and cation may occur, which might be a limiting factor for the proton mobility in compounds with high dopant levels.

The fundamental thermodynamic parameters describing the defect chemistry of a proton conductor with perovskite structure can be extracted through the equilibrium constants associated with the applicable defect creation reactions. According to the Equations 12 and 10 that represent these defects,

$$
\begin{aligned}
& \frac{1}{2} \mathrm{O}_{2}+\mathrm{V}_{\mathrm{O}}^{\bullet \bullet} \stackrel{K 1}{\longleftrightarrow} \mathrm{O}_{\mathrm{O}}^{\mathrm{x}}+2 h^{\cdot} \\
& \mathrm{H}_{2} \mathrm{O}_{\text {(gas) }}+\mathrm{V}_{\mathrm{O}}^{\bullet}+\mathrm{O}_{\mathrm{O}}^{\mathrm{x}} \longleftrightarrow 2 \mathrm{OH}_{\mathrm{O}}^{\bullet}
\end{aligned}
$$

the concentration of different charge carriers can be expressed as (Equations 13 and 14):

$$
\begin{aligned}
& p=K_{1}\left[\mathrm{~V}_{\mathrm{O}}^{\bullet}\right]^{1 / 2} p_{\mathrm{O}_{2}}^{1 / 4} \\
& {\left[\mathrm{H}^{\bullet}\right]=K_{2}\left[\mathrm{~V}_{\mathrm{O}}^{\bullet}\right]^{1 / 2} p_{\mathrm{H}_{2} \mathrm{O}}^{1 / 2}}
\end{aligned}
$$

where $\mathrm{K}_{1}$ and $\mathrm{K}_{2}$ are the equilibrium constants of the Equations 10 and $12, p,\left[\mathrm{H}^{*}\right]$ and $\left[\mathrm{V}_{0}^{*}\right]$ are the concentration of electron holes, protons and vacancies, respectively, $p_{\mathrm{O}_{2}}$ and $p_{\mathrm{H}_{2} \mathrm{O}}$ the oxygen and water vapor partial pressures. Then, the generic electroneutrality condition is proposed for doped $\mathrm{BaZrO}_{3}$ or $\mathrm{BaCeO}_{3}$ as (Equation 15)

$$
2\left[\mathrm{~V}_{\mathrm{O}}^{* *}\right]+p+\left[\mathrm{H}^{\bullet}\right]=\left[\mathrm{M}_{\mathrm{Zr}, \mathrm{Ce}}^{\prime}\right]
$$


where $\left[\mathrm{M}_{\mathrm{Zr}, \mathrm{Ce}}^{\prime}\right]$ is the concentration of trivalent dopant on $\mathrm{Zr}$ or Ce-site. By the in situ thermogravimetry analysis the water solubility can be measured in a given perovskite proton conductor. In addition, thermodynamic parameters may be also estimated from the equilibrium constants associated with the defect creation reactions. In the evaluation of the defect chemistry formation and its relationship with the transport properties, some process variables such as dopant concentration, temperature, water and oxygen partial pressure must be considered. These variables are closely related to the charge carriers concentration (oxygen vacancies, protons, electrons and holes) and for example, at higher temperatures and under oxidizing conditions it has been shown that protons, oxygen vacancies and electron holes can all coexist ${ }^{38,50}$.

Basically, from thermogravimetry experimental data the weight change can be collected, assuming it is caused only by water uptake. Considering this, the water incorporation expression represented by the Equation 10 provides an estimated proton concentration. Then, the equilibrium constant, $\mathrm{K}_{\mathrm{H}_{2} \mathrm{O}}$ for the water incorporation reaction can be written as (Equation 16)

$$
\mathrm{K}_{\mathrm{H}_{2} \mathrm{O}}=\frac{\left[\mathrm{OH}_{\mathrm{O}}^{\bullet}\right]}{p_{\mathrm{H}_{2} \mathrm{O}}\left[\mathrm{V}_{\mathrm{O}}^{\bullet \bullet}\right]\left[\mathrm{O}_{\mathrm{O}}^{\mathrm{x}}\right]}
$$

where $\left[\mathrm{OH}_{\mathrm{O}}^{*}\right]$ and $\left[\mathrm{V}_{\mathrm{o}}^{*}\right]$ are the proton and vacancy concentration, respectively, $p_{\mathrm{H}_{2} \mathrm{O}}$ is the water partial pressure and $\left[\mathrm{O}_{\mathrm{O}}^{\mathrm{x}}\right]$ the oxygen ions in the normal oxygen sites.

Given specific oxygen, water partial pressure and determined dopant level, the concentration of a specific mobile species can be calculated from Equations 13 to 15 . The calculation itself is not trivial and although the hydrogen concentration is taken from the Equation 16, the equilibrium constant cannot be determined directly from it, because $\left[\mathrm{V}_{\mathrm{o}}^{*}\right]$ and $\left[\mathrm{O}_{\mathrm{O}}^{\mathrm{x}}\right]$ are not known. In addition to these charge carriers, electron holes can also occur in cerate and zirconate based compounds. Under oxidizing conditions, for example, oxygen vacancies can be consumed in a process represented by Equation 12, previously mentioned. In addition, some doped barium cerate compounds may present a good stability under reducing atmosphere, and even the oxygen ion conductors based on cerium oxide show significant electronic conduction at $\mathrm{pO}_{2}$ lower than $10^{-20}$ atm at $600{ }^{\circ} \mathrm{C}^{51}$.

The enthalpy $\Delta \mathrm{H}_{\mathrm{H}_{2} \mathrm{O}}$ and the entropy $\Delta \mathrm{S}_{\mathrm{H}_{2} \mathrm{O}}$ of water incorporation can be determined through the equation that relates $\mathrm{K}_{\mathrm{H}_{2} \mathrm{O}}$ with these thermodynamic parameters (Equation 17):

$$
\mathrm{K}_{\mathrm{H}_{2} \mathrm{O}}=\exp \left(\Delta \mathrm{S}_{\mathrm{H}_{2} \mathrm{O}} / \mathrm{R}\right) \exp \left(-\Delta \mathrm{H}_{\mathrm{H}_{2} \mathrm{O}} / \mathrm{RT}\right)
$$

where $\mathrm{R}$ is the universal gas constant and $\mathrm{T}$ the absolute temperature. From a simple consideration of defects formation, under oxidizing atmosphere changes in the sample weight are expected, reflecting in the increase in the $\mathrm{O}_{\mathrm{O}}^{\mathrm{x}}$ content and changes in water concentration. With these assumptions, the equilibrium constant, $\mathrm{K}_{\mathrm{H}_{2} \mathrm{O}}$ can be rewritten as (Equation 18)

$$
\mathrm{K}_{\mathrm{H}_{2} \mathrm{O}}=\frac{4\left[\mathrm{OH}_{\mathrm{O}}^{\bullet}\right]^{2}}{p_{\mathrm{H}_{2} \mathrm{O}}\left(6-\left[\mathrm{Y}_{\mathrm{Zr}}^{\prime}\right]-\left[\mathrm{OH}_{\mathrm{O}}^{\bullet}\right]-\mathrm{p}\right)\left(\left[\mathrm{Y}_{\mathrm{Zr}}^{\prime}\right]-\left[\mathrm{OH}_{\mathrm{O}}^{\bullet}\right]-\mathrm{p}\right)}
$$

In this case it is usual to consider that the hole concentration, $\mathrm{p}$ is negligible $(\mathrm{p}=0)$ and applying the methodology of Equation 18 to the thermogravimetry data measured, the value of $\mathrm{K}_{\mathrm{H}_{2} \mathrm{O}}$ can be evaluated as a function of the reciprocal temperature, in Arrhenius form, as represented in Figure 4. It is worth noting the presence of two regions with different characteristics, and at low temperature the linearity has been clearly observed in Yamazaki, Babilo and Haile ${ }^{52}$,

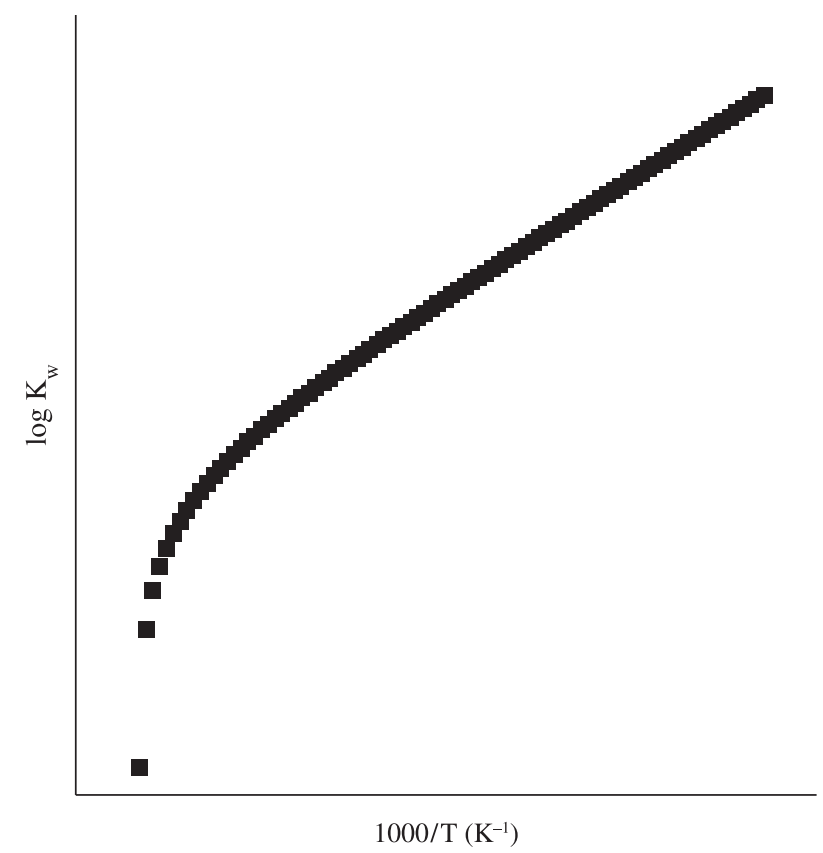

Figure 4. Arrhenius representation of the equilibrium constant for the water incorporation reaction.

as expected. However, at high temperatures the behavior deviates substantially from linearity, displaying a strongly change in slope, at approximately $450{ }^{\circ} \mathrm{C}^{[53,54]}$. This behavior may be related to certain physical-chemistry phenomena, such as the temperature dependences of the entropies and enthalpies of water incorporation, beyond the influences of hole and oxygen concentrations at high temperatures seem to be more eligible ${ }^{38,55-57}$. Thereby, as a consequence of a physical artifact, $\Delta \mathrm{H}_{\mathrm{H}_{2} \mathrm{O}}$ and $\Delta \mathrm{S}_{\mathrm{H}_{2} \mathrm{O}}$ extracted from the curve may present inconsistent values in a wide temperature range. Not surprisingly, the resulting hydration entropies and enthalpies from $50-500{ }^{\circ} \mathrm{C}$ ( -22 to $-26 \mathrm{~kJ} / \mathrm{mol}$ and -39 to $-44 \mathrm{~J} / \mathrm{K} . \mathrm{mol}$, respectively) of yttrium doped barium zirconate found by Yamazaki et al. ${ }^{52}$ were smaller in magnitude than those reported in the literature. As an example, at higher temperature range, $550-900{ }^{\circ} \mathrm{C}$, the values of $\Delta \mathrm{H}_{\mathrm{H}_{2} \mathrm{O}}$ and $\Delta \mathrm{S}_{\mathrm{H}_{2} \mathrm{O}}$ reported by Kreuer et al. ${ }^{54}$ were $-93.3 \mathrm{~kJ} / \mathrm{mol}$ and $-103.2 \mathrm{~J} / \mathrm{K}$. mol, respectively, showing the difference must be due to a physical phenomenon and not just to an experimental artifact.

The fundamental thermodynamic parameters describing the defect chemistry of a proton conductor with perovskite structure can be extracted through the equilibrium constants associated with the applicable defect creation reactions. Then, the knowledge of the constant behavior with increasing temperature allows one to describe the water incorporation process in a given solid electrolyte ${ }^{58,59}$. With this, extracting such parameters from Figure 4 also permits to evaluate if certain perovskite is thermodynamically more favorable to water solubility, being closely associated with the transport properties of that material.

The proton transport mechanism has been studied by several groups. Two main mechanisms are well accepted, although there are still some divergences: the vehicular and the Grotthuss mechanisms ${ }^{60-62}$. In the former, proton diffuses on a vehicle like $\mathrm{H}_{3} \mathrm{O}^{+}$, for example. This mechanism can be found in some compounds such as $\mathrm{HF}, \mathrm{HCl}$, Nafion and $\mathrm{SnO}_{2} \cdot \mathrm{nH}_{2} \mathrm{O}^{25,63}$. In the latter, the Grotthuss mechanism, proton diffuses by a combination between a molecular reorientation around the oxygen and jump of the proton from oxygen 
to a nearest neighbor ion. The orientation of the $\mathrm{O}-\mathrm{H}$ group directs the $\mathrm{H}^{+}$close to the adjacent oxygen ion. The rotation period to a complete revolution is about $10^{-12} \mathrm{~s}$ and the jumping time $\sim 10^{-9} \mathrm{~s}$ in which is considered the limiting step of the conduction mechanism ${ }^{64,65}$. That mechanism is found in solid acid salts $\left(\mathrm{CsH}_{2} \mathrm{PO}_{4}\right)$ and perovskites like $\mathrm{BaCeO}_{3}$ and $\mathrm{BaZrO}_{3}$, reported in this work. A schematic representation of the Grotthus mechanism is presented in Figure 5.

It is important to observe that during the proton jump, the $\mathrm{O}-\mathrm{H}$ bond of a site is withheld, while simultaneously the $\mathrm{O}-\mathrm{H}$ bond with the adjacent oxygen ion is formed (Figure 5b). The proton transfer is carried out by a mechanism in which the formation of one bond is followed by breaking another one, and the strong interaction between the proton and the two oxygen neighbors avoid the need of extra energy to break the $\mathrm{O}-\mathrm{H}$ bond ${ }^{66}$.

\section{Chemical Stability}

In spite of compounds based on barium cerate have relatively high proton conductivity values at relatively high temperatures, these materials present low chemical stability under $\mathrm{CO}_{2}$ and $\mathrm{H}_{2} \mathrm{O}$ atmospheres, leading to the formation of alkaline earth metal carbonates (Equation 19) or hydroxides (Equation 20) ${ }^{67,68}$.

$$
\begin{aligned}
& \mathrm{BaCeO}_{3}+\mathrm{CO}_{2} \rightarrow \mathrm{BaCO}_{3}+\mathrm{CeO}_{2} \\
& \mathrm{BaCeO}_{3}+\mathrm{H}_{2} \mathrm{O} \rightarrow \mathrm{Ba}(\mathrm{OH})_{2}+\mathrm{CeO}_{2}
\end{aligned}
$$

This reactivity may lead to degradation of the electrolyte, limiting its application in electrochemical devices that act under severe conditions like solid oxide fuel cells (SOFCs) or catalytic membrane reactors. Scholten $\mathrm{MJ}$ et al. ${ }^{69}$ showed that $\mathrm{BaCeO}_{3}$ reacts with $\mathrm{CO}_{2}$ at high temperatures. However, to keep stable the SOFC behavior, the operation temperature should present a maximum value and the $\mathrm{CO}_{2}$ partial pressure should be low enough to minimize the electrolyte reaction. Thereby, different variable processes and changes in the electrolyte have been investigated to solve the problem of low stability, without damaging its high proton conductivity, which is also essential for the commercialization of that material. The replacement of $\mathrm{Ce}^{4+}$ ( $\mathrm{R}=0,87 \AA$ ) by ions of different sizes such as $\mathrm{Nd}^{3+}(\mathrm{R}=0.983 \AA)$, $\mathrm{Gd}^{3+}(\mathrm{R}=0.938 \AA)$ and $\mathrm{Zr}^{4+}(\mathrm{R}=0.72 \AA)$, for example, has been an alternative found to minimize the effects of cerate reactivity in $\mathrm{CO}_{2}$ rich atmospheres ${ }^{68}$. For this purpose, it has been observed that the addition of cations to the $\mathrm{ABO}_{3}$ system of barium cerate contributes significantly to improve its stability in $\mathrm{CO}_{2}$ saturated atmospheres. The influence of different ionic radii on the lattice parameters of the unit cell has been also investigated, leading to changes in the cell volume, as expected, mainly with increasing the $\mathrm{Zr}^{4+}$ level, with its small size.
However, the increase of the chemical stability observed with addition of different dopants is also followed by a significant reduction of the proton conductivity, undesirable for commercialization of that material. Following this point of view, it has been noted that through the manipulation of chemical species and dopant concentration in $\mathrm{BaCeO}_{3}$, it is possible to get a specific chemical composition that results in an electrolyte or electrode material with higher conductivity and improved chemical stability. Liu et al. ${ }^{70}$ showed that the replacement of low contents of $\mathrm{Ce}^{4+}$ in the $\mathrm{B}$-sites by $\mathrm{Zr}^{4+}$ ions in the $\mathrm{BaZr}_{0.1} \mathrm{Ce}_{0.7} \mathrm{Y}_{0.1} \mathrm{Yb}_{0.1} \mathrm{O}_{3-\mathrm{d}}$ composition and also inserting $\mathrm{Yb}^{3+}$ cations as part of the defect formation mechanism were quite satisfactory for obtaining a relatively high ionic conductivity. At $450{ }^{\circ} \mathrm{C}$, for example, the ionic conductivity observed in water vapor saturated atmosphere was $1.10^{-2} \mathrm{~S}_{\mathrm{cm}} \mathrm{cm}^{-1}$, approximately twice the value of the conductivity of the similar compound without $\mathrm{Yb}^{3+}$. Moreover, the system anode/ electrolyte, Ni-BaZr ${ }_{0.1} \mathrm{Ce}_{0.7} \mathrm{Y}_{0.1} \mathrm{Yb}_{0.1} \mathrm{O}_{3-\delta} / \mathrm{BaZr}_{0.1} \mathrm{Ce}_{0.7} \mathrm{Y}_{0.1} \mathrm{Yb}_{0.1} \mathrm{O}_{3-\delta}$, showed to be largely tolerant to hydrogen sulfide $\left(\mathrm{H}_{2} \mathrm{~S}\right)$ and power densities relatively high $\left(\sim 1,1 \mathrm{~W} \cdot \mathrm{cm}^{-2}\right)$ were attained at $750{ }^{\circ} \mathrm{C}$.

\section{Conductivity of Barium Zirconate}

Unlike proton conductor membranes based on barium cerate, barium zirconate displays excellent chemical stability in $\mathrm{CO}_{2}{ }^{37,71}$, which is very attractive for applications in devices that require aggressive environments. The first reports about doped barium zirconate listed in the early 1990 s presented this material as a poor proton conductor in comparison to $\mathrm{BaCeO}_{3}$ based electrolytes. Although the electrical conductivities of both perovskites differ in approximately two orders of magnitude, the maximum electrical conductivity value of the doped barium zirconate was $1.2 \times 10^{-4} \mathrm{~S} . \mathrm{cm}^{-1}$ at $600{ }^{\circ} \mathrm{C}$. Afterwards the properties of this solid electrolyte were better evaluated and substantially revised in 1999, when Kreuer ${ }^{72}$ reported the conductivity of the yttrium-doped barium zirconate as $5.10^{-5}{\mathrm{~S} . \mathrm{cm}^{-1}}$ at a temperature as low as $140{ }^{\circ} \mathrm{C}$. This result was quickly confirmed by Schober and Bohn in $2000^{73}$. The interpretation on the limited conductivity of $\mathrm{BaZrO}_{3}$ at $600{ }^{\circ} \mathrm{C}$ came from its refractory nature, leading to sintered samples with submicron average grain size and high grain boundaries density. As a consequence, the large electrical resistivity of the interfaces results in a material with low total electrical conductivity suggesting, in this case, a more detailed investigation of the influence of the microstructure on the electrical conductivity, for obtaining improved macroscopic transport properties. Following this reasoning, Yamazaki et al. ${ }^{74}$ showed that submicron grain size in $\mathrm{BaZr}_{0.8} \mathrm{Y}_{0.2} \mathrm{O}_{3-\delta}$ is a highly resistive factor to the intergranular component of the total electrical conductivity. Through the study of the proton transport properties in samples with different average grain sizes $\left(\mathrm{D}_{\text {grain }}\right)$, it was observed that the proton

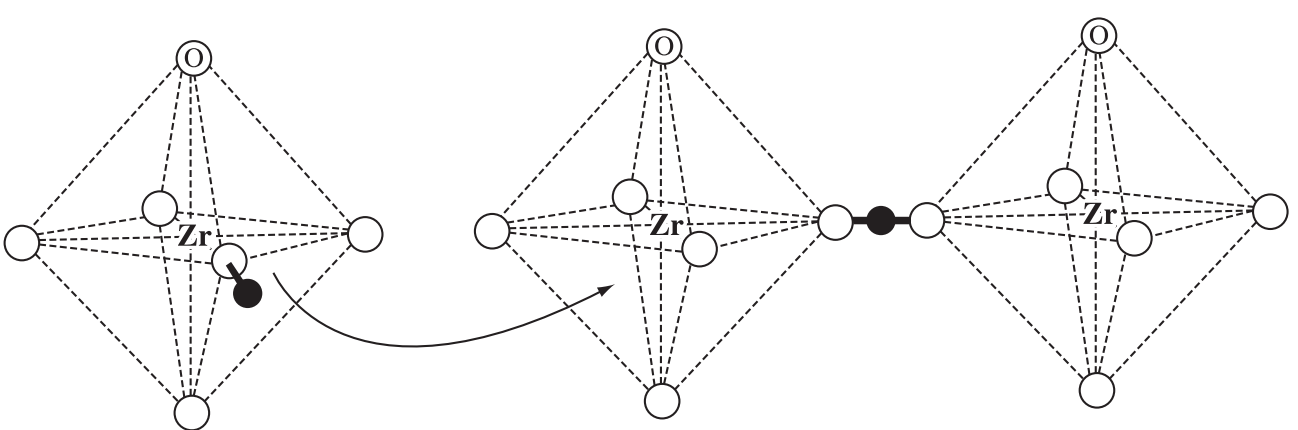

(a) (b)

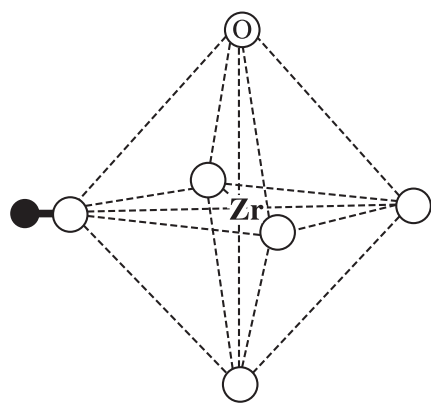

(c)

Figure 5. Scheme of the Grotthus mechanism for proton transport. 
conductivity of the electrolyte with larger $\mathrm{D}_{\text {grain }}$ values was at least 2.5 times higher. Moreover, at $450^{\circ} \mathrm{C}$, for example, the total electrical conductivity attained by this electrolyte was $\sim 1 \times 10^{-2} \mathrm{~S} . \mathrm{cm}^{-1}$, higher than the total ionic conductivity of samarium-doped ceria at this same temperature, as illustrated in Figure 6.

The relatively high proton conductivity results (at intermediate temperatures) obtained for the $\mathrm{BaZr}_{0.8} \mathrm{Y}_{02} \mathrm{O}_{3-\delta}$ solid electrolyte and also its high chemical stability in $\mathrm{CO}_{2}$-rich atmosphere, established this material as a promising solid electrolyte. However, it is important to emphasize that the aggressive processing conditions for obtaining this material, which generally requires very high sintering temperatures $\left(>1600{ }^{\circ} \mathrm{C}\right)$, may lead to stoichiometry losses and further reduction of the conductivity. In this case, special attention must be taken for development of new methods of chemical synthesis and processing techniques for obtaining ceramic powders of high sinterability. The major target is to decrease the sintering temperature and to avoid the deleterious effect due to barium losses. One should consider that a previous quantitative analysis for determining cation contents in the sintered sample is of prime importance, to minimize the influence of nonstoichiometry on the transport properties.

Among several techniques for thin films deposition, the Pulsed Laser Deposition (PLD) technique ${ }^{75,76}$ has been suggested as a useful solution for minimizing stoichiometry deviations because of its relative low deposition temperature $\left(\sim 400-800{ }^{\circ} \mathrm{C}\right)$. Over the last few years this technique has attracted a great attention due to its simplicity and versatility for deposition of a wide variety of materials such as metallic superconductors, metals, polymers, ceramic materials and semiconductor oxides. Interesting results, like obtaining structures in nanometric scale and progress in this method have been attained, mainly by the possibility of varying process parameters such as plasma density, ionization level, energy of the ion, substrate temperature and geometric arrangement of the deposition chamber. Particularly, the ability of manipulating the film growth kinetics trying to obtain a material with optimized properties is highly desirable. Other great advantage of PLD is the fact that the stoichiometry of the target can be preserved in the deposited film, avoiding segregation process. In the case of the electrochemical devices for hydrogen production, for example, the efficiency is directly related with the protons transport rate through the membrane,

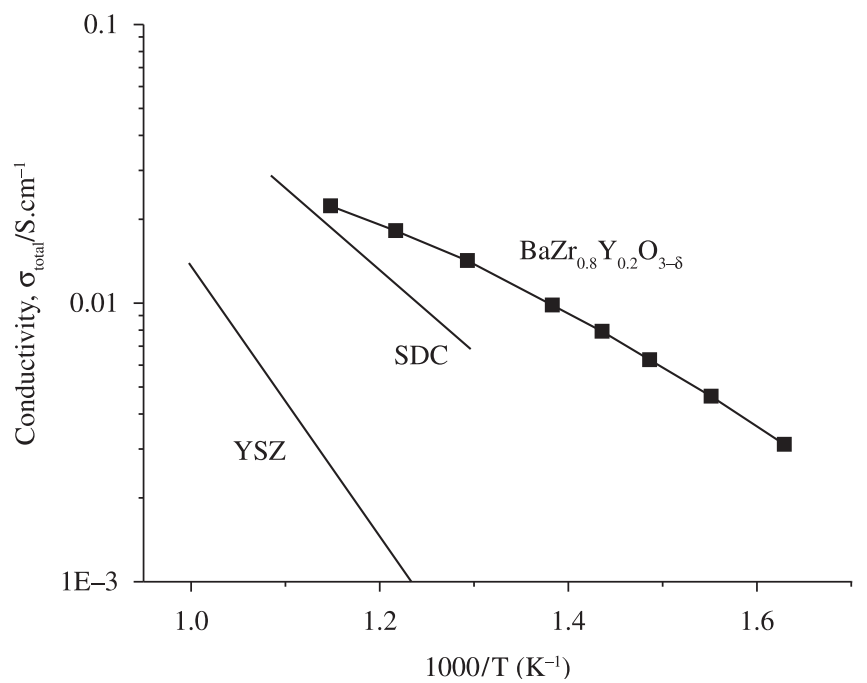

Figure 6. Arrhenius plots of the total electrical conductivity of doped barium zirconate and some electrolytes commonly studied. Figure adapted from Yamazaki, Sanchez and Haile ${ }^{74}$. which may be optimized by forming ultrathin films. Moreover, there is the possibility of depositing electrolyte/electrode double layer, giving possibility to decrease the overpotential due to the interfacial resistance between the components. Our objective here is not to give to the reader a concise detail about that technique, but only to expose some advantages that seem to be very useful for the development of this research area. The development of micro solid oxide fuel cells (-SOFCs) refers to another context in which the PLD method is situated. The thin films deposition applied to the fabrication of this type of device is a rising field and of great interest due to some reasons. The typical operation temperature of a SOFC based on perovskite proton conductors comprehends the range from 500 to $750{ }^{\circ} \mathrm{C}$. Operation temperatures relatively high may lead to complications with the sealing of the device as well as stability losses between the components of the cell ${ }^{77,78}$, not excluding the energy consumption to heat the system. Currently, lowering that temperature is one of the main targets of the research groups. To compensate performance losses with decreasing operation temperature, the production of cell components as thin films with lower ohmic resistance has been investigated. The choice of a more appropriated deposition technique is highly influenced by the material and characteristic of the desired film. The research line involving the manufacture of submicron solid oxide fuel cells has been developed by a select research group, because the development of all instrumentation necessary to the construction and also to optimizing the deposition system parameters is not trivial. Although the first works on thin films deposition by PLD have been reported about 30 years ago, that research field is relatively recent and it has been more highlighted only over the last 5 years. Some works involving the mechanism of ceramic oxide deposition by PLD for fabrication of $\mu$-SOFC have been reported in the literature. Solid electrolytes and electrode components based on perovskites, electrolytes such as gadolinium doped ceria (GDC), yttrium stabilized zirconia (YSZ) and lanthanum gallate also have been deposited by this technique ${ }^{79-81}$. Thin films of high relative density and with nanometric grain size have been attained, and the relation between structure and microstructure of those oxides with their electric properties has been evaluated. As an example, the microstructure and the electrochemical properties of cathode materials $\left(\mathrm{La}_{0.8} \mathrm{Sr}_{0.2} \mathrm{MnO}_{3}\right.$ and $\mathrm{La}_{0.5} \mathrm{Sr}_{0.5} \mathrm{CoO}_{3}$ ) obtained by PLD were studied by Koep et al. ${ }^{82}$ Although the results do not reveal any change in the impedance diagram of thin films with submicrometric thickness, the crystalline structure after deposition is dependent on the temperature and the substrate material. The power densities $\left(\mathrm{P}_{\mathrm{D}}\right)$ of micro SOFCs containing electrolyte membranes (YSZ) with thickness varying from 50 to $150 \mathrm{~nm}$ were studied by F. B. Prinz ${ }^{83}$ and relatively high $P_{D}$ values were achieved at lower temperatures. At the temperature of $400{ }^{\circ} \mathrm{C}$, the electrochemical system $\mathrm{H}_{2}, \mathrm{Pt} / \mathrm{YSZ} / \mathrm{Pt}$, Air presented a power density of $400 \mathrm{~mW} \cdot \mathrm{cm}^{-2}$, significantly higher than most values reported, at this same temperature, for SOFCs with thick components. Besides decreasing the electrolyte thickness, the higher charge carriers transport rate at the interfaces electrode/electrolyte due to the reduction of the interfacial resistance, given the larger contact surface, were the main factors which contributed to increasing that micro device performance. Applying their feedback on thin films deposition of proton conductors with perovskite structure, F. B. Prinz et al ${ }^{84}$ have recently evaluated the structural and microstructural properties of BYZ films with $100 \mathrm{~nm}$ thickness, approximately, as well as the fuel cell performance. In general, the power densities of the cells with ultrathin membranes supported on Si substrates and covered by platinum electrodes were higher in magnitude than reported thicker cells ${ }^{85,86}$. Considering the thickness of the proton membrane consisting of a few grains, the ohmic loss across the electrolyte was negligible at $450{ }^{\circ} \mathrm{C}$, as presented in the polarization 
curve. The cell overpotential, in this case, can be considered as the sum of the overpotentials at the electrodes. According to previous results, assuming the electrode losses were dominated by cathodic reactions ${ }^{87}$, the calculated charge transfer coefficient was in the range of 0.2-0.3, in agreement with reference values of cathode reactions in typical proton conducting fuel cells ${ }^{88}$. Although further analysis is needed for a quantitative understanding about those reactions and the influence of the ultrathin film electrodes in power density, one can conclude that the deposition of electrolytic membranes with submicrometric thickness is of prime importance to minimize the cell overpotential, as expected.

\section{Final Considerations}

In general, protonic conductors with perovskite structure have attracted much attention over the last few years due to their high applicability in electrochemical devices for energy generation and hydrogen production. Therefore, the investigation and knowledge of the defect chemistry and proton transport properties in these ceramic electrolytes are of great interest and important to enlarge the possibilities of application in an industrial scale process.

Specifically for cerates and zirconates with barium in their general formula, the required typically high sintering temperatures have been an obstacle to guarantee the desired stoichiometry and to avoid the deleterious effects, due to the barium deficiency, on the electrical properties of the sintered material. Lacking of chemical synthesis methods really effectives and processing techniques for ceramic powder production are limiting factors, which have led these materials to be so little explored. Obtaining nanoparticles with morphological control and high surface activity might be an early departure for getting ceramic membranes of high relative density at lower temperatures $\left(<1300^{\circ} \mathrm{C}\right)$.

The chemical instability of solid electrolytes based on barium cerate in $\mathrm{CO}_{2}$-rich atmospheres at high temperatures has taken several research groups to employ barium zirconate as an alternative electrolyte in research work for application purposes. The manipulation of the elements in the $\mathrm{BaCeO}_{3}$ structure by inserting dopant cations, mainly at B-sites, has been an alternative to minimize the chemical reactivity and also to optimize the ionic conductivity of that material. Although several reports have commented about the relatively low conductivity of zirconates in relation to barium cerates, some results show that the large electrical resistivity due to the high grain boundaries density can be reduced simply via grain growth. Electrical conductivity values relatively high $\left(\sim 1 \times 10^{-2}{\left.\mathrm{~S} . \mathrm{cm}^{-1}\right)}^{-1}\right.$ at intermediate temperatures $\left(450{ }^{\circ} \mathrm{C}\right)$ have been attained for both $\mathrm{BaCeO}_{3}$ and $\mathrm{BaZrO}_{3}$ based compounds, leading the proton conductors with perovskite structure to a highlight position among the most studied ceramic solid electrolytes.

\section{Acknowledgements}

To FAPESP (Proc. 05/53241-9) for financial support. E.C.C. Souza acknowledges CNPq (Proc. 500311/2009-9) for the postdoctoral fellowship.

\section{References}

1. Navrotsky A and Weidner DJ. Perovskite: a structure of great interest to geophysics and materials science. American Geophysical Union; 1989. Geophysical Monograph.

2. Iwahara H, Esaka T, Uchida H and Maeda N. Proton conduction in sintered oxides and its application to steam electrolysis for hydrogen production. Solid State Ionics. 1981; 3-4:359-363.
3. Uchida $\mathrm{H}$, Maeda $\mathrm{N}$ and Iwahara $\mathrm{H}$. Relation between proton and hole conduction in $\mathrm{SrCeO}_{3}$-based solid electrolytes under water-containing atmospheres at high temperatures. Solid State Ionics. 1983; 11(2):117-124.

4. Iwahara H, Uchida H, Ono K and Ogaki K. Proton Conduction in Sintered Oxides Based on $\mathrm{BaCeO}_{3}$. Journal of The Electrochemical Society. 1988; 135(2):529-533

5. Feng M and Goodenough JB. A superior oxide-ion electrolyte. European Journal of Solid State and Inorganic Chemistry. 1994; 31(8-9):663-672.

6. Teraoka Y, Zhang HM, Okamoto K and Yamazoe N. Mixed ionicelectronic conductivity of $\mathrm{La}_{1-\mathrm{x}} \mathrm{Sr}_{\mathrm{x}} \mathrm{Co}_{1-\mathrm{y}} \mathrm{Fe}_{\mathrm{y}} \mathrm{O}_{3-\delta}$ perovskite-type oxides. Materials Research Bulletin. 1988; 23(1):51-58.

7. Carter S, Selcuk A, Chater RJ, Kajda J, Kilner JA and Steele BCH. Oxygen transport in selected nonstoichiometric perovskite-structure oxides. Solid State Ionics. 1992; 53:597-605.

8. Fukui T, Ohara $\mathrm{S}$ and Kawatsu S. Conductivity of $\mathrm{BaPrO}_{3}$ based perovskite oxides. Journal of Power Sources. 1998; 71(1-2):164-168.

9. Dimos D and Mueller C. Perovskite thin films for high-frequency capacitor applications. Annual Review of Materials Research. 1998; 28:397-419.

10. Shaw T, Trolier-McKinstry $S$ and McIntyre P. The properties of ferroelectric films at small dimensions. Annual Review of Materials Science. 2000; 30:263-298.

11. Spinicci R, Tofanari A, Delmastro A, Mazza D and Ronchetti S. Catalytic properties of stoichiometric and non-stoichiometric $\mathrm{LaFeO}_{3}$ perovskite for total oxidation of methane. Materials Chemistry and Physics. 2002; 76(1):20-25.

12. Forni L and Rossetti I. Catalytic combustion of hydrocarbons over perovskites. Applied Catalysis B: Environmental. 2002; 38(1):29-37.

13. Kishi H, Mizuno $\mathrm{Y}$ and Chazono H. Base-metal electrode-multilayer ceramic capacitors: Past, present and future perspectives. Japanese Journal of Applied Physics Part 1. 2003; 42(1):1-15.

14. Jonker GH. Magnetic compounds with perovskite structure.4. Conducting and non-conducting compounds. Physica. 1956; 22(8):707-722.

15. DeTeresa J, Ibarra M, Algarabel P, Ritter C, Marquina C, Blasco J et al. Evidence for magnetic polarons in the magnetoresistive perovskites. Nature. 1997; 386(6622):256-259.

16. Moritomo Y, Asamitsu A, Kuwahara H and Tokura Y. Giant magnetoresistance of manganese oxides with a layered perovskite structure. Nature. 1996; 380(6570):141-144.

17. Moret M, Devillers M, Worhoff $\mathrm{K}$ and Larsen P. Optical properties of $\mathrm{PbTiO}_{3}, \mathrm{PbZr}_{\mathrm{x}} \mathrm{Ti}_{1-\mathrm{x}} \mathrm{O}_{3}$, and $\mathrm{PbZrO}_{3}$ films deposited by metalorganic chemical vapor on $\mathrm{SrTiO}_{3}$. Journal of Applied Physics. 2002; 92(1):468-474.

18. Jona F, Shirane $\mathrm{G}$ and Pepinsky R. Optical study of $\mathrm{PbZrO}_{3}$ and $\mathrm{NANBO}_{3}$ single crystal. Physical Review. 1955; 97(6):1584-1590.

19. Weber M, Bass M and Demars G. Laser action and spectroscopic properties of $\mathrm{Er}^{3+}$ in $\mathrm{YAlO}_{3}$. Journal of Applied Physics. 1971; 42(1):301.

20. Rao K and Yoon K. Review of electrooptic and ferroelectric properties of barium sodium niobate single crystals. Journal of Materials Science. 2003; 38(3):391-400.

21. Ihringer J, Maichle J, Prandl W, Hewat A and Wroblewski T. Crystal-structure of the ceramic superconductor $\mathrm{BaPb}_{0.75} \mathrm{Bi}_{0.25} \mathrm{O}_{3}$. Z. Physik B-Condensed Matter. 1991; 82(2):171-176.

22. Cava RJ, Batlogg B, Krajewski JJ, Farrow R, Rupp LW, White AE et al. Superconductivity near 30 - $\mathrm{K}$ without copper-the $\mathrm{Ba}_{0.6} \mathrm{~K}_{0.4} \mathrm{BiO}_{3}$ perovskite. Nature. 1988; 332(6167):814-816.

23. Sampathkumar T, Srinivasan $\mathrm{S}$, Nagarajan $\mathrm{T}$ and Balachandran $\mathrm{U}$. Properties of $\mathrm{YBa}_{2} \mathrm{Cu}_{3} \mathrm{O}_{7-\delta}-\mathrm{BaBiO}_{3}$ composite superconductors. Applied Superconductivity. 1994; 2(1):29-34.

24. Norby T. Solid-state protonic conductors: principles, properties, progress and prospects. Solid State Ionics. 1999; 125(1-4):1-11.

25. Kreuer KD. Proton conductivity: materials and applications. Chemistry of Materials. 1996; 8(3):610-641. 
26. Momirlan M and Veziroglu TN. The properties of hydrogen as fuel tomorrow in sustainable energy system for a cleaner planet. International Journal of Hydrogen Energy. 2005; 30(7):795-802.

27. Moriarty $P$ and Honnery D. Hydrogen's role in an uncertain energy future. International Journal of Hydrogen Energy. 2009; 34(1):31-39.

28. Tao $\mathrm{S}$ and Irvine JTS. J. Conductivity studies of dense yttrium-doped $\mathrm{BaZrO}_{3}$ sintered at $1325^{\circ} \mathrm{C}$. Solid State Chemistry. 2007; 180(12):3493-3503.

29. Phair JW and Badwal SPS. Review of proton conductors for hydrogen separation. Ionics. 2006; 12(2):103-115.

30. Knight KS. Structural phase transitions, oxygen vacancy ordering and protonation in doped $\mathrm{BaCeO}_{3}$ : results from time-of-flight neutron powder diffraction investigations. Solid State Ionics. 2001; 145(1-4):275-294.

31. Hoffmann A. Examinations of compounds with Perovskite structure. Zeitschrift für Physikalische Chemie B. 1935; 28(1):65-77.

32. Jacobson AJ, Tofield BC and Fender BEF. Structures of $\mathrm{BaCeO}_{3}, \mathrm{BaPrO}_{3}$ and $\mathrm{BaTbO}_{3}$ by neutron-diffraction - lattice paramenter relations and ionic radii in o-perovskites. Acta Crystallographica B. 1972; 28:956.

33. Iwahara $\mathrm{H}$, Uchida $\mathrm{H}$ and Morimoto K. High temperature solid electrolyte fuel-cells using perovskite-type oxide based on $\mathrm{BaCeO}_{3}$. Journal of the Electrochemical Society. 1990; 137(2):462-465.

34. Islam MS. Ionic transport in $\mathrm{ABO}(3)$ perovskite oxides: a computer modelling tour. Journal of Materials Chemistry. 2000; 10(5):1027-1038.

35. Etsell TH and Flengas SN. Electrical properties of solid oxide electrolytes. Chemical Reviews. 1970; 70(3):339.

36. Nowick AS and Du Y. High temperature proton conductors with perovskite-related structures. Solid State Ionics. 1995; 77:137-146.

37. Iwahara H, Yajima T, Hibino T, Ozaki K and Suzuki H. Protonic conduction in calcium, strontium and barium zirconates. Solid State Ionics. 1993; 61(1-3):65-69.

38. Bonanos N. Transport properties and conduction mechanism in high temperature protonic conductors. Solid State Ionics. 1992; 53-56:967-974.

39. Kroger F and Vink V. Solid State Physics. New York: Academic Press; 1956.

40. Glockner R, Islam MS and Norby T. Protons and other defects in $\mathrm{BaCeO}_{3}$ : a computational study. Solid State Ionics. 1999; 122(1-4):145-156.

41. Makovec D, Samardzija Z and Kolar D. Solid solubility of neodymium in $\mathrm{BaCeO}_{3}$. Journal of the American Ceramic Society. 1997; 80(12):3145-3150.

42. $\mathrm{Ma} \mathrm{G}$, Shimura $\mathrm{T}$ and Iwahara $\mathrm{H}$. Ionic conduction and nonstoichiometry in $\mathrm{Ba}_{\mathrm{x}} \mathrm{Ce}_{090} \mathrm{Y}_{010} \mathrm{O}_{3}$. Solid State Ionics. 1998; 110(1-2):103-110.

43. Eguchi K, Setoguchi T, Inoue T and Arai H. Electrical properties of ceria based oxides and their application to solid oxide fuel-cells. Solid State Ionics. 1992; 52(1-3):165-172.

44. Khani Z, Jacquin MT, Taillades G, Marrony M, Jones DJ and Roziere J. New synthesis of nanopowders of proton conducting materials. A route to densified proton ceramics. Journal of Solid State Chemistry. 2009; 182(4):790-798.

45. Bassano A, Buscaglia V, Viviani M, Bassoli M, Buscaglia MT, Sennour $\mathrm{M}$ et al. Synthesis of Y-doped $\mathrm{BaCeO}_{3}$ nanopowders by a modified solidstate process and conductivity of dense fine-grained ceramics. Solid State Ionics. 2009; 180(2-3):168-174.

46. Orlov AV, Shlyakhtin OA, Vinokurov AL, Knotko AV, Tret'yakov YD. Preparation and properties of fine $\mathrm{BaCeO}_{3}$ powders for low-temperature sintering. Inorganic Materials. 2005; 41(11):1194-1200.

47. Cai J, Laubernds K, Galasso FS, Suib SL, Liu J, Shen XF et al. Preparation method and cation dopant effects on the particle size and properties of $\mathrm{BaCeO}_{3}$ perovskites. Journal of the American Ceramic Society. 2005; 88(10):2729-2735.

48. Davies RA, Islam MS and Gale JD. Dopant and proton incorporation in perovskite-type zirconates. Solid State Ionics. 1999; 126(3-4):323-335.

49. Islam MS. Computer modelling of defects and transport in perovskite oxides. Solid State Ionics. 2002; 154:75-85.
50. Slade RCT and Singh N. Generation of charge-carriers and an H/D isotope effect in proton-conducting doped barium cerate ceramics. Journal of Materials Chemistry. 1991; 1(3):441-445.

51. Lai W and Haile SM. Impedance spectroscopy as a tool for chemical and electrochemical analysis of mixed conductors: a case study of ceria. Journal of the American Ceramic Society. 2005; 88(11):2979-2997.

52. Yamazaki Y, Babilo P and Haile SM. Defect Chemistry of YttriumDoped Barium Zirconate: a Thermodynamic Analysis of Water Uptake. Chemistry of Materials. 2008; 20(20):6352-6357.

53. Schober $\mathrm{T}$ and Bohn HG. Water vapor solubility and electrochemical characterization of the high temperature proton conductor $\mathrm{BaZr}_{09} \mathrm{Y}_{01} \mathrm{O}_{205}$ Solid State Ionics. 2000; 127(3-4):351-360.

54. Kreuer KD, Adams S, Munch W, Fuchs A, Klock U and Maier J. Proton conducting alkaline earth zirconates and titanates for high drain electrochemical applications. Solid State Ionics. 2001; 145(1-4):295-306.

55. Nomura $\mathrm{K}$ and Kageyama $\mathrm{H}$. Transport properties of $\mathrm{Ba}\left(\mathrm{Zr}_{0.8} \mathrm{Y}_{0.2}\right) \mathrm{O}_{3}$ perovskite. Solid State Ionics. 2007; 178(7-10):661-665.

56. Kosacki I and Tuller HL. Mixed conductivity in $\mathrm{SrCe}_{095} \mathrm{Yb}_{005} \mathrm{O}_{3}$ protonic conductors. Solid State Ionics. 1995; 80(3-4):223-229.

57. He T, Kreuer KD, Baikov YM and Maier J. Impedance spectroscopic study of thermodynamics and kinetics of a Gd-doped $\mathrm{BaCeO}_{3}$ single crystal. Solid State Ionics 1997; 95(3-4):301-308.

58. Poulsen FW. Method for calculating ionic and electronic defect concentrations in proton containing perovskites. Journal of Solid State Chemistry. 1999; 143(1):115-121.

59. Bonanos $\mathrm{N}$ and Poulsen FW. Considerations of defect equilibria in high temperature proton-conducting cerates. Journal of Materials Chemistry. 1999; 9(2):431-434.

60. Noam A. The Grotthuss mechanism. Chemical Physics Letters. 1995; 244(5-6):456-462.

61. Goodenough JB. Solid State Microbatteries. Designing a Solid Electrolyte III. Proton Conduction and Composites. New York: Plenum Press; 1990.

62. Kreuer KD, Dippel Th, Hainovsky N and Maier J. Proton conductivitycompounds and their structural and chemical peculiarities. Berichte der Bunsengesellschaft für Physikalische Chemie. 1992; 96(11):1736-1742.

63. Chipot C, Gorb LG and Rivall JL. Proton-transfer in the monohydrated and the dehydrated complexes of $\mathrm{HF}$ and $\mathrm{HCl}-\mathrm{AN}$ MP2/6-31+G (asteriskasterisk) AB-Initio study in the self-consistent reaction field model of salvation. Journal of Chemical Physics. 1994; 98(6):1601-1607.

64. Cherry M, Islam MS, Gale JD and Catlow CRA. Computational studies of protons in perovskite-structured oxides. Journal of Chemical Physics. 1995; 99(40):14614-14618.

65. Munch W, Seifert G, Kruer KD and Maier J. A quantum molecular dynamics study of the cubic phase of $\mathrm{BaTiO}_{3}$ and $\mathrm{BaZrO}_{3}$. Solid State Ionics. 1997; 97(1-4):39-44.

66. Cherry M, Islam MS, Gale JD and Catlow CRA. Computational studies of proton migration in perovskite oxides. Solid State Ionics. 1995; 77:207-209.

67. Kreuer KD. On the development of proton conducting materials for technological applications. Solid State Ionics. 1997; 97(1-4):1-15.

68. Ryu KH and Haile SM. Chemical stability and proton conductivity of doped $\mathrm{BaCeO}_{3}-\mathrm{BaZrO}_{3}$ solid solutions. Solid State Ionics. 1999 125(1-4):355-367.

69. Scholten MJ, Schoonman J, Miltenburg JC and Oonk HAJ. Synthesis of strontium and barium cerate and their reaction with carbon-dioxide Solid State Ionics. 1993; 61(1-3):83-91.

70. Yang L, Wang S, Blinn K, Liu M, Liu Z, Cheng Z et al. Enhanced Sulfur and Coking Tolerance of a Mixed Ion Conductor for SOFCs: $\mathrm{BaZr}_{0.1} \mathrm{Ce}_{0.7} \mathrm{Y}_{0.2-\mathrm{x}} \mathrm{Yb}_{\mathrm{x}} \mathrm{O}_{3-\delta}$. Science. 2009; 326(5949):126-129.

71. Yajima T, Suzuki H, Yogo T and Iwahara H. Protonic conduction in $\mathrm{SrZrO}_{3}$ based oxides. Solid State Ionics. 1992; 51(1-2):101-107.

72. Kreuer KD. Aspects of the formation and mobility of protonic charge carriers and the stability of perovskite-type oxides. Solid State Ionics. $1999 ; 125(1-4): 285-302$ 
73. Bohn $\mathrm{HG}$ and Schober T. Electrical conductivity of the high-temperature proton conductor $\mathrm{BaZr}_{0.9} \mathrm{Y}_{0.1} \mathrm{O}_{2.95}$. Journal of the American Ceramic Society. 2000; 83(4):768-772.

74. Yamazaki Y, Sanchez RH and Haile SM. High Total Proton Conductivity in Large-Grained Yttrium-Doped Barium Zirconate. Chemistry of Materials. 2009; 21(13):2755-2762.

75. Cheung JT. Pulsed Laser Deposition of Thin Films. New York: John Wiley and Sons; 1994.

76. Beckel D, Bieberle-Hütter A, Harvey A, Infortuna A, Muecke UP, Prestat $\mathrm{M}$ et al. Thin films for micro solid oxide fuel cells. Journal of Power Sources. 2007; 173(1):325-345.

77. Steele BCH and Heinzel A. Materials for fuel-cell technologies. Nature. 2001; 414(6861):345-352.

78. Singhal SC and Kendall K. High temperature solid oxide fuel cells: fundamentals, design and applications. Elsevier; 2003.

79. Joo HJ and Choi MG. Simple fabrication of micro-solid oxide fuel cell supported on metal substrate. Journal of Power Sources. 2008; 182(2):589-593.

80. Shin J, Li P and Mazumder J. Pulsed laser deposition of the yttriastabilized zirconia films. Thin Solid Films. 2008; 517(2):648-651.

81. Infortuna A, Harvey AS and Gauckler LJ. Microstructures of CGO and YSZ thin films by pulsed laser deposition. Advanced Functional Materials. 2008; 18(1):127-135.
82. Koep E. Microstructure and electrochemical properties of cathode materials for SOFCs prepared via pulsed laser deposition. Journal of Power Sources. 2006; 161(1):250-255.

83. Prinz FB. The influence of size scale on the performance of fuel cells. Solid State Ionics. 2004; 175(1-4):789-795.

84. Shim HJ, Park SJ, An J, Gür MT, Kang S and Prinz FB. IntermediateTemperature Ceramic Fuel Cells with Thin Film Yttrium-Doped Barium Zirconate Electrolytes. Chemistry of Materials. 2009; 21(14):3290-3296.

85. D'Epifani A, Fabbri E, Di Bartolomeo E, Licoccia S and Traversa E. Synthesis and characterization of $\mathrm{BaZr}_{0.8} \mathrm{Y}_{0.2} \mathrm{O}_{3}$ protonic conductor for intermediate temperature solid oxide fuel cells (IT-SOFCs). Solid State Ionics. 2007; 972:31-36.

86. D’Epifani A, Fabbri E, Di Bartolomeo E, Licoccia S and Traversa E. Design of $\mathrm{BaZr}_{0.8} \mathrm{Y}_{0.2} \mathrm{O}_{3-\delta}$ protonic conductor to improve the electrochemical performance in intermediate temperature solid oxide fuel cells (IT-SOFCs). Fuel Cells. 2008; 8(1):69-76.

87. Hibino T, Hashimoto A, Suzuki M and Sano M. A solid oxide fuel cell using Y-doped $\mathrm{BaCeO}_{3}$ with Pd-loaded $\mathrm{FeO}$ anode and $\mathrm{Ba}_{0.5} \mathrm{Pr}_{0.5} \mathrm{CoO}_{3}$ cathode at low temperatures. Journal of the Electrochemical Society. 2002; 149:A1503-A1508.

88. Wang ZH, Wang CY and Chen KS. Two-phase flow and transport in the air cathode of proton exchange membrane fuel cells. Journal of Power Sources. 2001; 94:40-50. 